\title{
Investigation of heavy metals in frequently utilized medicinal plants collected from environmentally diverse locations of north western India
}

\author{
Alpana Kulhari ${ }^{1}$, Arun Sheorayan ${ }^{1}$, Somvir Bajar ${ }^{2}$, Susheel Sarkar ${ }^{3}$, Ashok Chaudhury ${ }^{1}$ and Rajwant K Kalia ${ }^{4}$
}

\begin{abstract}
The increasing prevalence of environmental pollution, especially soil contamination with heavy metals has led to their uptake in the human food chains through plant parts. Accumulation and magnification of heavy metals in human tissues through consumption of herbal remedies can cause hazardous impacts on health. Therefore, chemical profiling of nine heavy metals ( $\mathrm{Mn}, \mathrm{Cr}, \mathrm{Pb}, \mathrm{Fe}, \mathrm{Cd}, \mathrm{Co}, \mathrm{Zn}, \mathrm{Ni}$ and $\mathrm{Hg}$ ) was undertaken in stem and leaf samples of ten medicinal plants (Acacia nilotica, Bacopa monnieri, Commiphora wightii, Ficus religiosa, Glycyrrhiza glabra, Hemidesmus indicus, Salvadora oleoides, Terminalia bellirica, Terminalia chebula and Withania somnifera) collected from environmentally diverse regions of Haryana and Rajasthan states in North-Western India. Concentration of all heavy metals, except $\mathrm{Cr}$, was within permissible limits in the tested stem and leaf samples. Leaf samples had consistently more $\mathrm{Cr}$ compared to respective stem samples with highest concentration in leaf samples of Bacopa monnieri (13.19 $\pm 0.0480 \mathrm{ppm})$ and stem samples of Withania somnifera (4.93 $\pm 0.0185 \mathrm{ppm}$ ) both collected from Bahadurgarh (heavy industrial area), Haryana. This amount was beyond the permissible limit of 2.0 ppm defined by WHO for raw herbal material. Other two most perilous metals $\mathrm{Pb}(2.64 \pm 0.0260)$ and $\mathrm{Cd}(0.04 \pm 0.0274)$ were also recorded in Bahadurgarh region, although below permissible limits. Concentration of $\mathrm{Hg}$ remained below detectable levels in all the leaf and stem samples tested. These results suggested that cultivation of medicinal plants and other dietary herbs should be curtailed near environmentally polluted especially industrial areas for avoidance of health hazards.
\end{abstract}

Keywords: AAS; Heavy metals; Herbal plants; Soil pollution; Toxicity

\section{Introduction}

Herbal medicines being natural are preferred over synthetic remedies by a major section of the world. Since times immemorial, ancient Indians, Egyptians, Chinese and others have employed a variety of plants and plant products for curing all kinds of ailments. Approximately, 25000 plant based formulations are available in the indigenous medical texts (Gupta et al., 2004). Also, the modern pharmacopoeia contains at least $25 \%$ drugs derived from plants and many others which are synthetic analogues built on prototype compounds isolated from plants (Rao et al., 2004). The World Health Organization (WHO) estimated that $80 \%$ of the population of developing countries relies on traditional medicines, mostly plant

\footnotetext{
* Correspondence: rajwantkalia@yahoo.com

${ }^{4}$ Central Arid Zone Research Institute (CAZRI), Jodhpur, Rajasthan 342003, India

Full list of author information is available at the end of the article
}

drugs, for their primary health care needs (Planning Commission Report, 2000). Complementary and alternative medicine has received global attention in the last few years with a frequency of $31.4 \%$ population in industrialized societies, $42-69 \%$ in United States, 71\% Canadians and $90 \%$ British population consuming dietary supplements or natural health products (vitamins, minerals, amino acids, essential fatty acids, herbal products, traditional Chinese medicines, homeopathic medicines, and probiotics) for treatment, including elimination of disease causing agents, avoidance of side effects and for getting quality life (Szeto, 2007). The world market for herbal medicine, including herbal products and raw materials has been estimated to have an annual growth rate between 5 and $15 \%$. Total global herbal drug market is estimated at US $\$ 62$ billion and is expected to grow to US $\$ 5$ trillion by the year 2050 (Joshi et al., 2004). 
Accumulation of toxic industrial effluents in the soil is continuously increasing due to fast urbanization and extensive pollution of the environment. Among these toxic substances, presence of heavy metals (HMs; atomic weights $63.5-200.6 \mathrm{~g} \mathrm{~mol}^{-1}$ and a specific gravity greater than $5 \mathrm{~g} \mathrm{~cm}^{-3}$ ) which are ubiquitous in nature, cause serious harmful effects on living organisms (Nies, 1999; Lee and Lee, 2002). Plants are sensitive to environmental conditions and they accumulate these HMs in their harvestable parts (via root uptake, foliar adsorption and deposition of specific elements in leaves) and intensity of this uptake process changes the overall elemental composition of the plant (Olajire and Ayodele, 2003). Uptake, accumulation and concentration of HMs in plants is influenced by various attributes including atmospheric depositions (depend on traffic densities, metal mining and smelting operations), concentration and bioavailability of HMs in soil (through addition of pesticides and sewage sludge), the nature of soil where herbs are grown ( $\mathrm{pH}$ and organic matter concentration), individual plant performance (degree of maturity of the plant, time of harvest) and manufacturing conditions of herbal drugs (grinding weights, lead-releasing containers and manufacturing utensils) etc (Nwoko and Mgbeahuruike, 2011). Different HMs have different transmitting rates from soilto-plant, based on transfer coefficients of metals viz: $\mathrm{Cd}$, $\mathrm{Tl}$ and $\mathrm{Zn}$ are readily taken up by plants because of higher transfer coefficient, whereas $\mathrm{Cu}, \mathrm{Co}, \mathrm{Cr}$, and $\mathrm{Pb}$ are stably bound to the soil structures and show minimum transfer to plants from soil due to lower transfer coefficient (Kloke et al., 1984). Some metals ( $\mathrm{Mg}, \mathrm{Mn}$ and $\mathrm{Zn}$ ) play a vital role in proper growth and development of the plant being directly or indirectly involved in various biological functions of enzyme activation and molecular metabolism. Very little information is available about potential influence of metals on pharmacological activity of natural drugs obtained from medicinal plants. Metal mediated hazardous impacts can be direct or indirect via binding of metals with pharmacologically active substances or by manipulating the pharmacokinetics (Weber and Konieczyński, 2003).

Consumption of raw herbal drugs from the medicinal plants, grown in polluted sites can cause serious consequences on human health. Higher levels of these elements are carcinogenic and affects the central nervous system $(\mathrm{Hg}, \mathrm{Pb}$ and $\mathrm{As})$, cause kidney damage and liver dysfunction $(\mathrm{Hg}, \mathrm{Pb}, \mathrm{Cd}$ and $\mathrm{Cu})$, are toxic to skin, bones and teeth $(\mathrm{Ni}, \mathrm{Cd}, \mathrm{Cu}$ and $\mathrm{Cr}$ ) and have adverse effects on memory and reproductive system (Hussain et al., 2011). For getting desirable therapeutic benefits, quality of these herbal products must be ensured in terms of metal contamination. Therefore, there is an urgent need for quick assessment of these heavy metals in medicinal plants to control the level of contaminants in herbal raw materials. Generally, three methods-atomic absorption spectrophotometry (AAS), inductively coupled plasma (ICP) and neutron activation analysis (NAA) (Kunle et al., 2012) have been employed for quantitative estimation of metals present in herbal raw material as an admixture or in trace amounts.

This study was designed to investigate the levels of nine heavy metals $(\mathrm{Mn}, \mathrm{Cr}, \mathrm{Pb}, \mathrm{Fe}, \mathrm{Cd}, \mathrm{Co}, \mathrm{Zn}, \mathrm{Ni}$ and $\mathrm{Hg}$ ) in leaf and stem samples of ten medicinal plants (Acacia nilotica, Bacopa monnieri, Commiphora wightii, Ficus religiosa, Glycyrrhiza glabra, Hemidesmus indicus, Salvadora oleoides, Terminalia bellirica, Terminalia chebula and Withania somnifera) collected from environmentally diverse regions of North Western India (Haryana and Rajasthan states) using AAS. The collection sites were shortlisted on the basis of presence of contaminated soil and atmospheric polluting units (presence of industries, heavy traffic sites and site located near to petrol pumps) whereas the medicinal plants were selected on the basis of their significant importance in the Ayurveda along with their frequent utilization in novel pharmaceutical preparations, preparation of traditional drug formulations, food supplements and their diverse medicinal properties. General description and economic importance of medicinal plants undertaken in the present study is given in Table 1.

\section{Materials and methods}

Leaf and stem samples of Acacia nilotica, Bacopa monnieri, Commiphora wightii, Ficus religiosa, Glycyrrhiza glabra, Hemidesmus indicus, Salvadora oleoides, Terminalia bellirica, Terminalia chebula and Withania somnifera were collected separately from different geographical locations of Haryana and Rajasthan states of India. Sampling was done from five districts namely Jhunjhunu, Churu, Bahadurgarh, Fathebad and Mahendergarh (Table 2). The collected material was washed thoroughly with running tap water followed by washing with deionized autoclaved water to remove the dust particles and possible parasites. They were shade dried, powdered and stored in closed air tight bottles for further experimentation.

Heavy metal analysis was done according to AOAC (1995) using flame atomic absorption spectroscopy in ten medicinal plants using wet digestion method (Meena et al., 2010). Standards of Fe, Pb, Mn, Cr, Zn, Cd, Co, $\mathrm{Hg}$ and $\mathrm{Ni}$ procured from Merck, Germany, were used as reference analytes for quantitative estimation of heavy metals as well as accurate calibration and quality assurance of each analyte. The standard stock solutions (1000 ppm) were diluted to obtain working standard solutions ranging from $1 \mathrm{ppm}$ to $10 \mathrm{ppm}$ and stored at $4^{\circ} \mathrm{C}$. An acidity of $0.1 \%$ nitric acid was maintained in all the solutions. A calibration curve was plotted between measured absorbance and concentration (ppm). All the samples were analyzed in 
Table 1 General description and economic importance of medicinal plants used in the study

\begin{tabular}{|c|c|c|c|c|c|c|}
\hline Scientific name & $\begin{array}{l}\text { Common } \\
\text { name }\end{array}$ & Family & Habit & Part used & Medicinal properties & References \\
\hline $\begin{array}{l}\text { Acacia nilotica (L.) } \\
\text { Willd. Ex Delile }\end{array}$ & Babul, kikar & Mimosaceae & $\begin{array}{l}\text { Medium sized } \\
\text { tree }\end{array}$ & $\begin{array}{l}\text { Bark, roots, } \\
\text { seeds, gum, } \\
\text { pods }\end{array}$ & $\begin{array}{l}\text { Used to cure diarrhea, Aphrodisiac, } \\
\text { dressing of ulcers, Alzheimer's diseases, } \\
\text { wound ulcers, leprosy, leucoderma, } \\
\text { small pox, skin diseases, biliousness, } \\
\text { burning sensation and toothache. }\end{array}$ & Ali et al. (2012) \\
\hline $\begin{array}{l}\text { Bacopa monnieri (L.) } \\
\text { Pennell }\end{array}$ & Brahmi & Plantaginaceae & Perennial herb & Leaves & $\begin{array}{l}\text { Improve memory capacity, intellectual } \\
\text { activity and enhance the immune } \\
\text { function by increasing immunoglobulin } \\
\text { production. }\end{array}$ & $\begin{array}{l}\text { Morgan and Stevens } \\
\text { (2010) Yamada et al. } \\
\text { (2011) }\end{array}$ \\
\hline $\begin{array}{l}\text { Commiphora wightii } \\
\text { (Arn) Bhandari }\end{array}$ & Guggul & Burseraceae & $\begin{array}{l}\text { Balsamiferous } \\
\text { woody shrub }\end{array}$ & Bark, stem & $\begin{array}{l}\text { Active ingredients } E \text { and } Z \\
\text { guggulsterone in oleoresin gum have } \\
\text { lipid and cholesterol lowering activities } \\
\text { along with acting as anti- cancerous } \\
\text { compound. }\end{array}$ & Kulhari et al. (2012) \\
\hline Ficus religiosa L. & Peepal & Moraceae & $\begin{array}{l}\text { Large deciduous } \\
\text { tree }\end{array}$ & $\begin{array}{l}\text { Bark, leaves, } \\
\text { seeds, fruits, }\end{array}$ & $\begin{array}{l}\text { Used to cure asthma, cough, sexual } \\
\text { disorders, gonorrhea, skin diseases, } \\
\text { scabies, hiccup, tuberculosis, fever } \\
\text { and paralysis. }\end{array}$ & Makhija et al. (2010) \\
\hline Glycyrrhiza glabra L. & Mulethi & Fabaceae & Perennial herb & Roots & $\begin{array}{l}\text { Popularly used to treat ileitis, lung } \\
\text { inflammation, peptic ulcers, leaky } \\
\text { gut syndrome and irritable bowel } \\
\text { syndrome. }\end{array}$ & Krausse et al. (2004) \\
\hline $\begin{array}{l}\text { Hemidesmus indicus } \\
\text { L.R.Br. }\end{array}$ & Anantmul & Apocynaceae & $\begin{array}{l}\text { Perennial } \\
\text { climber }\end{array}$ & Leaves, stem & $\begin{array}{l}\text { Used in inflammation, cuts, wounds, } \\
\text { burns, skin and blood diseases, ulcers } \\
\text { and immunological disorders. }\end{array}$ & $\begin{array}{l}\text { Saravanan and Nalini } \\
(2007)\end{array}$ \\
\hline $\begin{array}{l}\text { Salvadora oleoides } \\
\text { Decne. }\end{array}$ & Jaal, Pilu & Salvadoraceae & Small tree & Leaves, roots & $\begin{array}{l}\text { The leaves have anti-inflammatory, } \\
\text { analgesic and antiulcer activities. }\end{array}$ & Yadav et al. (2008) \\
\hline $\begin{array}{l}\text { Terminalia bellirica } \\
\text { (Gaertn.) Roxb. }\end{array}$ & Bahera & Combretaceae & Long tree & $\begin{array}{l}\text { Leaves, bark, } \\
\text { seed, roots, } \\
\text { flower }\end{array}$ & $\begin{array}{l}\text { Used in the treatment of gastric ulcer, } \\
\text { constipation, general debility and piles. }\end{array}$ & $\begin{array}{l}\text { Motamarri et al. } \\
\text { (2012) }\end{array}$ \\
\hline $\begin{array}{l}\text { Terminalia chebula } \\
\text { Retz. }\end{array}$ & Harītak, Harad & Combretaceae & $\begin{array}{l}\text { Medium to large } \\
\text { deciduous tree }\end{array}$ & $\begin{array}{l}\text { Leaves, bark, } \\
\text { fruits }\end{array}$ & $\begin{array}{l}\text { Used to cure anemia, anorexia, leprosy, } \\
\text { diarrhoea, bleeding piles, gout, arthritis, } \\
\text { epilepsy abdominal pain and asthma. }\end{array}$ & $\begin{array}{l}\text { Rao and Srinivas } \\
\text { (2006) }\end{array}$ \\
\hline $\begin{array}{l}\text { Withania somnifera } \\
\text { (L.) Dunal }\end{array}$ & Ashwagandha & Solanaceae & $\begin{array}{l}\text { Erect branched } \\
\text { shrub }\end{array}$ & $\begin{array}{l}\text { Leaves, stem, } \\
\text { roots, seed }\end{array}$ & $\begin{array}{l}\text { Used to promote health and longevity } \\
\text { along with revitalizing of body in } \\
\text { debilitated conditions and increasing } \\
\text { the capability of the individual to resist } \\
\text { adverse environmental factors. }\end{array}$ & $\begin{array}{l}\text { Weiner and Weiner } \\
\text { (1994) }\end{array}$ \\
\hline
\end{tabular}

Table 2 Collection of medicinal plants from Rajasthan and Haryana states

\begin{tabular}{|c|c|c|c|c|c|}
\hline Plant name & State & District & Latitude & Longitude & Status \\
\hline Acacia nilotica & Rajasthan & Jhunjhunu & $28.13^{\circ} \mathrm{N}$ & $75.40^{\circ} \mathrm{E}$ & Wild \\
\hline Bacopa monnieri & Haryana & Bahadurgarh & $28.68^{\circ} \mathrm{N}$ & $76.92^{\circ} \mathrm{E}$ & Wild \\
\hline Commiphora wightii & Haryana & Mahendergarh & $28.27^{\circ} \mathrm{N}$ & $76.15^{\circ} \mathrm{E}$ & Wild \\
\hline Ficus religiosa & Rajasthan & Jhunjhunu & $28.13^{\circ} \mathrm{N}$ & $75.40^{\circ} \mathrm{E}$ & Wild \\
\hline Glycyrrhiza glabra & Haryana & Bahadurgarh & $28.68^{\circ} \mathrm{N}$ & $76.92^{\circ} \mathrm{E}$ & Wild \\
\hline Hemidesmus indicus & Haryana & Fathebad & $29.52^{\circ} \mathrm{N}$ & $75.45^{\circ} \mathrm{E}$ & Wild \\
\hline Salvadora oleoides & Rajasthan & Churu & $26.60^{\circ} \mathrm{N}$ & $75.45^{\circ} \mathrm{E}$ & Wild \\
\hline Terminalia bellirica & Haryana & Fathebad & $29.52^{\circ} \mathrm{N}$ & $75.45^{\circ} \mathrm{E}$ & Wild \\
\hline Terminalia chebula & Haryana & Fathebad & $29.52^{\circ} \mathrm{N}$ & $75.45^{\circ} \mathrm{E}$ & Wild \\
\hline Withania somnifera & Haryana & Bahadurgarh & $28.68^{\circ} \mathrm{N}$ & $76.92^{\circ} \mathrm{E}$ & Wild \\
\hline
\end{tabular}


triplicate using Flame Atomic Absorption Spectrophotometer (AA 6300 Shimadzu, Japan) with Shimadzu, Wizard software. Optimized operating parameters for FAAS (Flame Atomic Absorption Spectrophotometer) of various heavy metals are listed in Table 3.

For heavy metal assessment, $5 \mathrm{~g}$ powder of each plant sample was taken into separate crucibles for charring for 3-4 hours. After charring, the samples were placed in the Muffle furnace at $500^{\circ} \mathrm{C}$ for $6 \mathrm{hrs}$ for ashing and were then cooled in the desiccators. Samples were digested in $20 \mathrm{ml}$ mixture of concentrated acids (nitric and perchloric acid in 9:1 ratio) for 3 hours in a water bath maintained at $70^{\circ} \mathrm{C}$ for dissolving the contents until a clear brownish solution was obtained using wet digestion method. After cooling, these solutions were reconstituted to $20 \mathrm{ml}$ volume with deionized autoclaved water. Each sample was filtered using whatmann filter paper (pore size $0.45 \mu$, Axiva) and stored in closed acid-washed glass vials. The stored samples were further used for analysis of heavy metals using flame atomic absorption spectroscopy. All experiments were done in triplicate for precision and accuracy of the results. Concentration of each metal was determined from absorbance value of each replicate and articulated in ppm on a dry-weight basis of the plant sample. Finally data was subjected to standard error calculation using SAS 9.3

\section{Results and discussion}

Atmosphere and soil are continuously being polluted with chemicals and heavy metals due to dynamic development of industries and motorization along with extensive use of pesticides and fertilizers. In turn, these pollutants and heavy metals are getting deposited in the plants growing in the polluted areas, which subsequently enter the human food chain via plant parts and/or extracts. Results of analysis of nine heavy metals $(\mathrm{Mn}, \mathrm{Cr}, \mathrm{Pb}, \mathrm{Fe}, \mathrm{Cd}, \mathrm{Co}, \mathrm{Zn}$, $\mathrm{Hg}$ and $\mathrm{Ni}$ ) done in stem and leaf samples of ten medicinal plant species are summarized in Tables 4 and 5 respectively. Significant difference in heavy metal concentration was observed among the plants in the two tissue samples (leaf and stem) collected from diverse geographical locations (Figures 1 and 2).
Manganese (Mn) is known as an essential trace element which acts as cofactor for many enzymes. It is less toxic than any other metal, however, can cause neurological disorders if its concentration exceeds $5 \mathrm{mg} / \mathrm{m}^{3}$ due to continuous exposure to manganese dust and fumes. In the present study, a wide variation occurred in Mn concentration in stem and leaf samples, with highest content in the stem samples of T. bellirica $(6.13 \mathrm{ppm})$ and leaf samples of $A$. nilotica (3.16 ppm) collected from Fathebad and Jhunjhunu, respectively. Mn concentration was more in the stem samples, ranging from 1.65 fold in A. nilotica to 7.03 fold in W. somnifera, compared to respective leaf samples except $C$. wightii wherein leaf samples accumulated more Mn (Figure 3). Chromium (Cr), regarded as one of the most toxic pollutants in the world is released by tanneries, steel industries, and sewage sludge applications along with alloys in motor vehicles. Its concentrations between $5-30 \mathrm{mg} / \mathrm{kg}$ are considered critical for plants as it causes heavy reduction in plant growth and yield. The permissible limit for $\mathrm{Cr}$ in raw herbal materials is $2.0 \mathrm{ppm}$ and that for finished products is $0.02 \mathrm{mg} /$ day (WHO, 2007). All the samples tested, except $A$. nilotica stem had $\mathrm{Cr}$ concentrations beyond the permissible limits defined by WHO. $\mathrm{Cr}$ concentration varied between $1.87 \pm 0.0202$ (A. nilotica) to $4.93 \pm 0.0185 \mathrm{ppm}$ (W. somnifera) in the stem samples while it varied from $8.53 \pm 0.0317$ (C. wightii) to $13.19 \pm$ $0.0480 \mathrm{ppm}$ (B. monnieri) in leaf samples. Cr concentration was 2.39 ( $H$. indicus) to 5.03 (B. monnieri) fold more in leaf samples compared to respective stem samples. Lead $(\mathrm{Pb})$ is highly hazardous for plants, animals and microorganisms. Continuous consumption of fertilizers, fuel combustion and sewage sludge are the major reasons leading to escalation in $\mathrm{Pb}$ pollution. The plant tissues tested (stem and leaf) contained extremely lower concentrations of $\mathrm{Pb}$ compared to the permissible limit of $10 \mathrm{ppm}$ defined by WHO (2007). Maximum amount of $\mathrm{Pb}$ was found in stem $(2.64 \pm 0.0260 \mathrm{ppm})$ and leaf $(0.81 \pm 0.0360 \mathrm{ppm})$ samples of $W$. somnifera collected from Bahadurgarh. $\mathrm{Pb}$ concentration was comparable in stem and leaf samples of A. nilotica, F. religiosa, G. glabra and T. chebula, however, it was 3.0-.4.5 fold more in stem samples of C. wightii, W. somnifera and B. monnieri.

Table 3 Operating parameters for FAAS of heavy metals

\begin{tabular}{|c|c|c|c|c|c|c|c|c|c|}
\hline \multirow[t]{2}{*}{ Parameters } & \multicolumn{9}{|c|}{ Heavy metals } \\
\hline & $M n$ & $\mathrm{Cr}$ & $\mathrm{Pb}$ & $\mathrm{Fe}$ & $\mathrm{Cd}$ & $\mathrm{Ni}$ & Co & $\mathrm{Zn}$ & $\mathrm{Hg}$ \\
\hline Wavelength (nm) & 279.5 & 357.9 & 283.3 & 248.3 & 228.8 & 232.0 & 240.7 & 213.9 & 253.7 \\
\hline Slit (nm) & 0.7 & 0.7 & 0.7 & 0.7 & 0.7 & 0.7 & 0.7 & 0.7 & 0.7 \\
\hline Acetylene flow rate ( $(/ \mathrm{min})$ & 1.8 & 1.8 & 1.8 & 1.8 & 1.8 & 1.8 & 1.8 & 1.8 & 1.8 \\
\hline $\mathrm{HCL}$ current $(\mathrm{mA})$ & 6 & 6 & 6 & 6 & 6 & 6 & 6 & 6 & 6 \\
\hline Air flow rate ( $1 / \mathrm{min})$ & 15 & 15 & 15 & 15 & 15 & 15 & 15 & 15 & 15 \\
\hline
\end{tabular}


Table 4 Concentration of heavy metals in stem samples of medicinal plants

\begin{tabular}{|c|c|c|c|c|c|c|c|c|c|c|}
\hline \multirow[b]{2}{*}{$\mathrm{S} / \mathrm{N}$} & \multirow[b]{2}{*}{ Plant species } & \multicolumn{9}{|c|}{ Mean heavy metal concentration in stem samples (ppm) } \\
\hline & & Mn & $\mathrm{Cr}$ & $\mathrm{Pb}$ & $\mathrm{Fe}$ & Cd & $\mathrm{Ni}$ & Co & $\mathrm{Zn}$ & $\mathrm{Hg}$ \\
\hline 1 & Acacia nilotica & $5.22 \pm 0.1040$ & $1.87 \pm 0.0202$ & $0.25 \pm 0.0088$ & $25.30 \pm 0.1464$ & $\mathrm{BDL}$ & $0.45 \pm 0.0240$ & $0.04 \pm 0.0088$ & $2.42 \pm 0.2173$ & $\mathrm{BDL}$ \\
\hline 2 & Bacopa monnieri & $4.23 \pm 0.0744$ & $2.62 \pm 0.0240^{*}$ & $2.34 \pm 0.0173$ & $17.16 \pm 0.1763$ & $0.02 \pm 0.0033$ & $0.26 \pm 0.0284$ & $0.05 \pm 0.0033$ & $6.75 \pm 0.1223$ & $\mathrm{BDL}$ \\
\hline 3 & Commiphora wightii & $2.51 \pm 0.0176$ & $2.87 \pm 0.0202^{*}$ & $0.63 \pm 0.0088$ & $19.45 \pm 0.2334$ & BDL & $0.55 \pm 0.0173$ & $0.02 \pm 0.0088$ & $7.74 \pm 0.0802$ & $\mathrm{BDL}$ \\
\hline 4 & Ficus religiosa & $4.52 \pm 0.0176$ & $2.67 \pm 0.0371^{*}$ & $0.36 \pm 0.0317$ & $24.35 \pm 0.1808$ & $0.02 \pm 0.0010$ & $0.64 \pm 0.0145$ & $0.12 \pm 0.01201$ & $4.17 \pm 0.0736$ & $\mathrm{BDL}$ \\
\hline 5 & Glycyrrhiza glabra & $4.78 \pm 0.0240$ & $3.56 \pm 0.0305^{*}$ & $0.41 \pm 0.0185$ & $21.21 \pm 0.0173$ & $0.03 \pm 0.0120$ & $0.06 \pm 0.0120$ & $0.20 \pm 0.0185$ & $5.52 \pm 0.0202$ & $\mathrm{BDL}$ \\
\hline 6 & Hemidesmus indicus & $5.43 \pm 0.0173$ & $4.89 \pm 0.0202^{*}$ & $0.66 \pm 0.0352$ & $15.42 \pm 0.0176$ & $0.03 \pm 0.0145$ & $1.07 \pm 0.0057$ & $0.23 \pm 0.0881$ & $7.13 \pm 0.0115$ & $\mathrm{BDL}$ \\
\hline 7 & Salvadora oleoides & $2.85 \pm 0.0218$ & $3.68 \pm 0.0202^{*}$ & $0.83 \pm 0.0088$ & $11.89 \pm 0.0317$ & $\mathrm{BDL}$ & $0.47 \pm 0.0115$ & $0.13 \pm 0.0173$ & $5.59 \pm 0.0317$ & $\mathrm{BDL}$ \\
\hline 8 & Terminalia bellirica & $6.13 \pm 0.0176$ & $3.80 \pm 0.0450^{*}$ & $0.63 \pm 0.0115$ & $16.34 \pm 0.0392$ & $0.03 \pm 0.0088$ & $0.43 \pm 0.0173$ & $0.21 \pm 0.0290$ & $5.46 \pm 0.0545$ & $\mathrm{BDL}$ \\
\hline 9 & Terminalia chebula & $5.67 \pm 0.0384$ & $2.92 \pm 0.0202^{*}$ & $0.62 \pm 0.0384$ & $16.19 \pm 0.0633$ & $0.03 \pm 0.0152$ & $0.64 \pm 0.0750$ & $0.20 \pm 0.0589$ & $6.32 \pm 0.0202$ & $\mathrm{BDL}$ \\
\hline 10 & Withania somnifera & $2.39 \pm 0.0218$ & $4.93 \pm 0.0185^{*}$ & $2.64 \pm 0.0260$ & $19.13 \pm 0.0176$ & $0.04 \pm 0.0088$ & $0.53 \pm 0.0296$ & $0.14 \pm 0.0152$ & $8.93 \pm 0.0264$ & $\mathrm{BDL}$ \\
\hline
\end{tabular}

*Beyond permissible limit defined by $\mathrm{WHO}$.

Iron $(\mathrm{Fe})$ is an important trace element and ironprotein mixtures play a vital role in metabolism in all living organisms. However, Fe overdose has been one of the leading reasons of death caused by toxicological agents in children younger than 6 years of age. Individuals demonstrate signs of gastro-intestinal toxicity after ingestion of more than $20 \mathrm{mg} / \mathrm{kg}$ iron while moderate intoxication occurs when ingestion of elemental Fe exceeds $40 \mathrm{mg} / \mathrm{kg}$ and ingestions exceeding $60 \mathrm{mg} / \mathrm{kg}$ can cause severe toxicity and may be lethal also (Spanierman, 2011). Here, highest content of $\mathrm{Fe}$ was found in A. nilotica stem samples $(25.30 \pm 0.1464 \mathrm{ppm})$ and $W$. somnifera leaf samples $(17.44 \pm 0.0202 \mathrm{ppm})$ collected from Jhunjhunu and Bahadurgarh, respectively. However, all concentrations were within the permissible limits. On the other hand, Annan et al., (2010) had reported essential element mediated toxicity due to higher accumulation of Fe (beyond the acceptable range $1000 \mu \mathrm{g} /$ day) in Ocimum canum, Clausena anisata and Rauwolfia vomitoria collected from
Ghana using wet digestion AAS. Fe concentrations were comparable (1.1-1.2 fold in S. oleoides, W. somnifera, T. bellirica, T. chebula, $H$. indicus, B. monnieri or higher (1.5-2.0 fold in A. nilotica, C. wightii, F. religiosa, G. glabra) in stem samples compared to respective leaf samples.

Cadmium (Cd) is another hazardous heavy metal which can cause significant reduction in plant yield at concentrations ranging from $5-30 \mathrm{mg} / \mathrm{kg}$. Recently, it is gaining more attention due to wide occurrence in water, soil, milk, dietary products, medicinal plants and herbal products. The major sources leading to accumulation of cadmium in soil and plants are phosphate fertilizers, non-ferrous smelters, lead and zinc mines, sewage sludge application and combustion of fossil fuels. All the samples analyzed in this study had $\mathrm{Cd}$ concentration within the acceptable range of $0.3 \mathrm{ppm}$ recommended by WHO (2007) for raw herbal material. Maximum amount of $\mathrm{Cd}$ was found in $W$. somnifera (0.04 $\mathrm{ppm}$ in both stem and leaf samples)

Table 5 Concentration of heavy metals in leaf samples of medicinal plants

\begin{tabular}{|c|c|c|c|c|c|c|c|c|c|c|}
\hline \multirow[b]{2}{*}{$\mathrm{S} / \mathrm{N}$} & \multirow[b]{2}{*}{ Plant species } & \multicolumn{9}{|c|}{ Mean heavy metal concentration in leaf samples (ppm) } \\
\hline & & Mn & $\mathrm{Cr}$ & $\mathrm{Pb}$ & $\mathrm{Fe}$ & $\mathrm{Cd}$ & $\mathrm{Ni}$ & Co & $\mathrm{Zn}$ & $\mathrm{Hg}$ \\
\hline 1 & Acacia nilotica & $3.16 \pm 0.0371$ & $8.73 \pm 0.0260^{*}$ & $0.21 \pm 0.0208$ & $16.01 \pm 0.0642$ & $\mathrm{BDL}$ & $0.59 \pm 0.0202$ & $0.19 \pm 0.0284$ & $3.09 \pm 0.0305$ & $\mathrm{BDL}$ \\
\hline 2 & Bacopa monnieri & $1.67 \pm 0.0425$ & $13.19 \pm 0.0480^{*}$ & $0.54 \pm 0.0417$ & $14.19 \pm 0.0633$ & $0.03 \pm 0.0088$ & $0.23 \pm 0.0317$ & $0.15 \pm 0.0115$ & $4.80 \pm 0.0907$ & $\mathrm{BDL}$ \\
\hline 3 & Commiphora wightii & $2.84 \pm 0.0688$ & $8.53 \pm 0.0317^{*}$ & $0.21 \pm 0.0145$ & $13.30 \pm 0.0264$ & $\mathrm{BDL}$ & $0.26 \pm 0.0348$ & $0.20 \pm 0.0200$ & $2.10 \pm 0.0173$ & $\mathrm{BDL}$ \\
\hline 4 & Ficus religiosa & $2.60 \pm 0.0392$ & $9.54 \pm 0.0202^{*}$ & $0.32 \pm 0.0240$ & $12.42 \pm 0.0272$ & $0.03 \pm 0.0057$ & $0.30 \pm 0.0296$ & $0.14 \pm 0.0120$ & $3.25 \pm 0.0240$ & $\mathrm{BDL}$ \\
\hline 5 & Glycyrrhiza glabra & $2.23 \pm 0.0305$ & $9.17 \pm 0.0173^{*}$ & $0.32 \pm 0.0233$ & $11.33 \pm 0.0296$ & $0.03 \pm 0.01660$ & $0.38 \pm 0.0233$ & $0.40 \pm 0.0251$ & $3.89 \pm 0.0348$ & $\mathrm{BDL}$ \\
\hline 6 & Hemidesmus indicus & $2.26 \pm 0.0260$ & $11.68 \pm 0.0480^{*}$ & $0.25 \pm 0.0088$ & $13.64 \pm 0.0115$ & $0.16 \pm 0.0260$ & $0.32 \pm 0.0173$ & $0.16 \pm 0.0251$ & $4.18 \pm 0.0212$ & $\mathrm{BDL}$ \\
\hline 7 & Salvadora oleoides & $0.89 \pm 0.0458$ & $10.48 \pm 0.0440^{*}$ & $0.52 \pm 0.0202$ & $11.03 \pm 0.0497$ & $\mathrm{BDL}$ & $0.48 \pm 0.0193$ & $0.15 \pm 0.0208$ & $4.40 \pm 0.0240$ & $\mathrm{BDL}$ \\
\hline 8 & Terminalia bellirica & $2.60 \pm 0.0348$ & $11.02 \pm 0.0808^{*}$ & $0.25 \pm 0.0120$ & $13.21 \pm 0.0202$ & $0.21 \pm 0.0176$ & $0.26 \pm 0.0257$ & $0.18 \pm 0.0145$ & $3.28 \pm 0.0145$ & $\mathrm{BDL}$ \\
\hline 9 & Terminalia chebula & $2.04 \pm 0.0264$ & $11.23 \pm 0.0887^{*}$ & $0.48 \pm 0.0290$ & $14.59 \pm 0.0352$ & $0.02 \pm 0.0120$ & $0.57 \pm 0.0264$ & $0.17 \pm 0.0264$ & $2.58 \pm 0.0237$ & $\mathrm{BDL}$ \\
\hline 10 & Withania somnifera & $0.34 \pm 0.0152$ & $12.34 \pm 0.0458^{*}$ & $0.81 \pm 0.0360$ & $17.44 \pm 0.0202$ & $0.04 \pm 0.0274$ & $0.19 \pm 0.0371$ & $0.14 \pm 0.0135$ & $4.10 \pm 0.0360$ & $\mathrm{BDL}$ \\
\hline
\end{tabular}




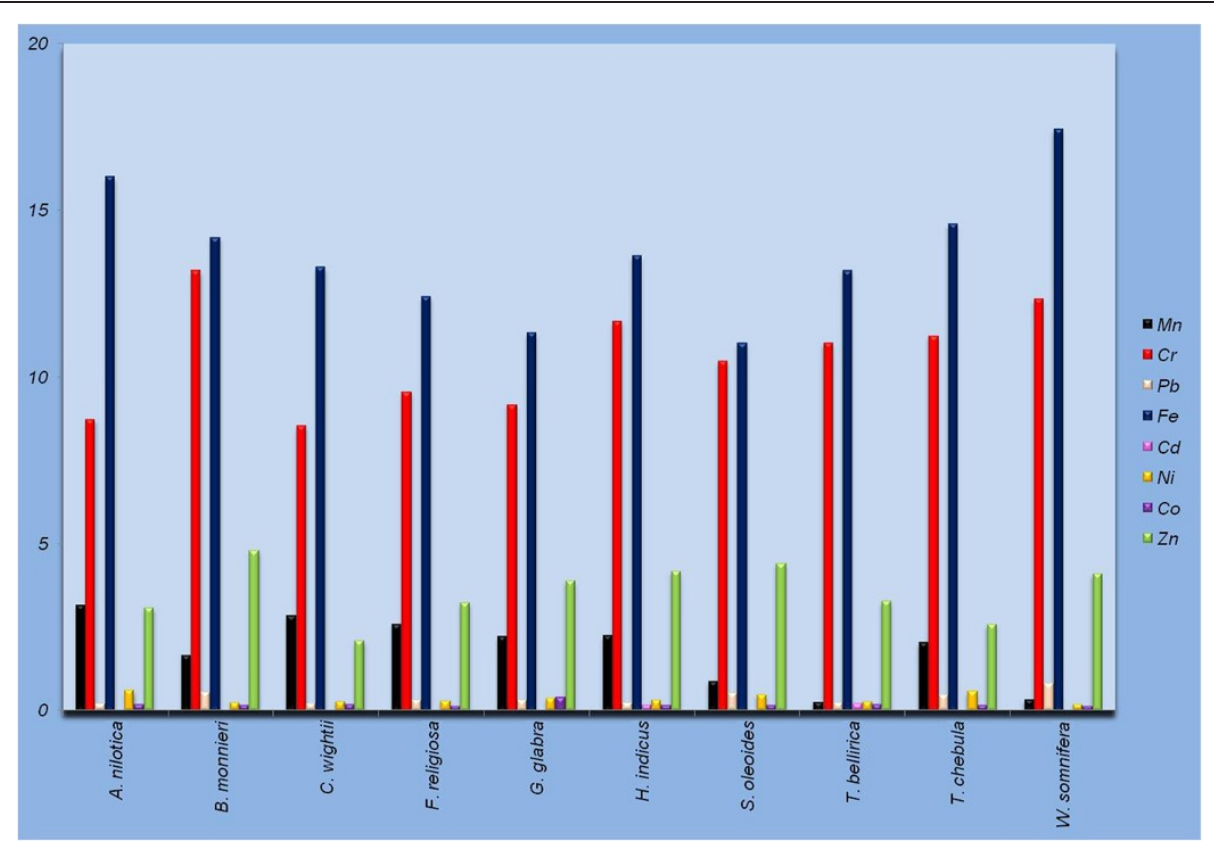

Figure 1 Heavy metal concentration in leaf samples of ten medicinal plants collected from different geographical regions.

collected from Bahadurgarh region, whereas, it remained undetected in stem samples of A. nilotica (Jhunjhunu), C. wightii (Mahendergarh) and S. oleoides (Churu). Cd concentration was comparable in stem and leaf samples of other plants except $T$. bellirica and $H$. indicus wherein $\mathrm{Cd}$ concentration was 5-7 fold more in leaf samples. Nickel (Ni) and Cobalt (Co) are trace elements required for a variety of biological processes. $\mathrm{Ni}$ is directly coordinated by proteins, whereas, Co is mainly used as a component of vitamin $B_{12}$ (Zhang et al., 2009). Nickel was recognized as an allergen of the year in 2008 by the American Contact Dermatitis Society and its minimal risk level was set to $0.2 \mu \mathrm{g} / \mathrm{m}^{3}$ for inhalation during 15364 days, however, no limit has been set for food stuffs

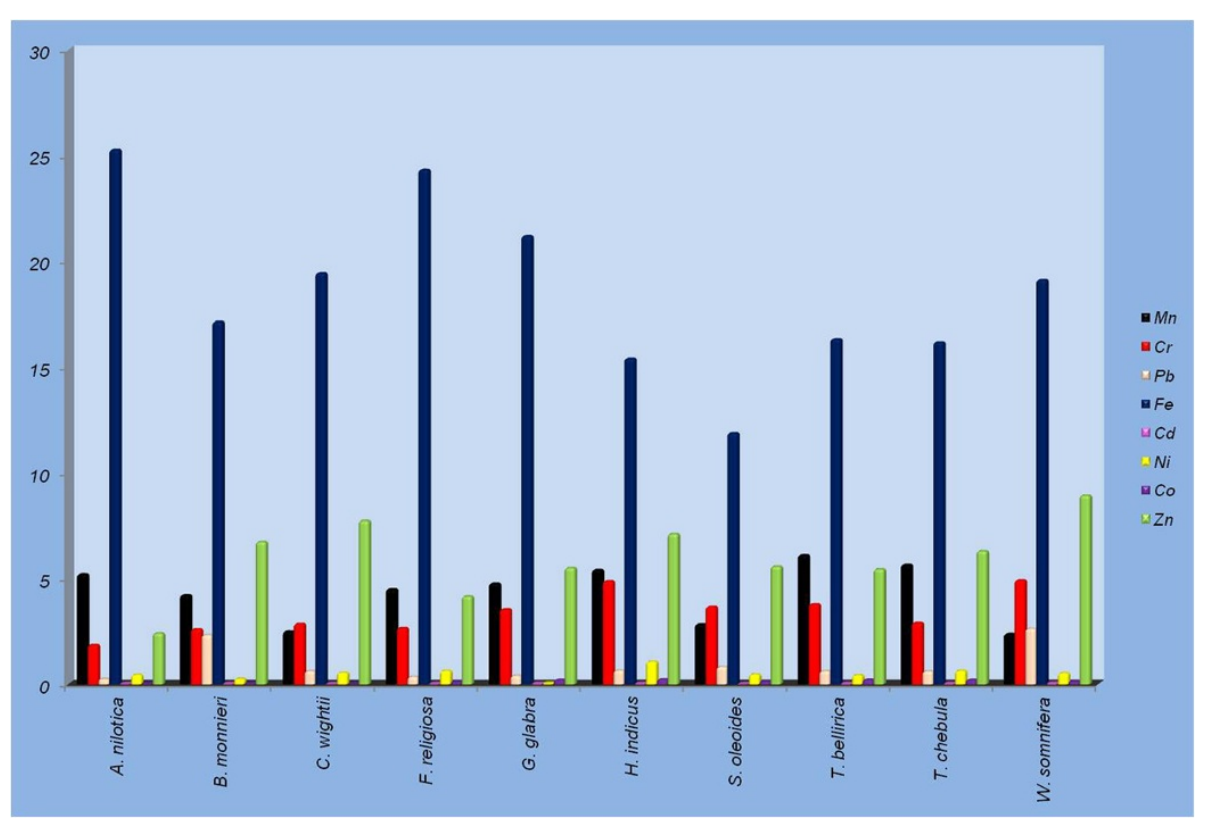

Figure 2 Heavy metal concentration in stem samples of ten medicinal plants collected from different geographical regions. 


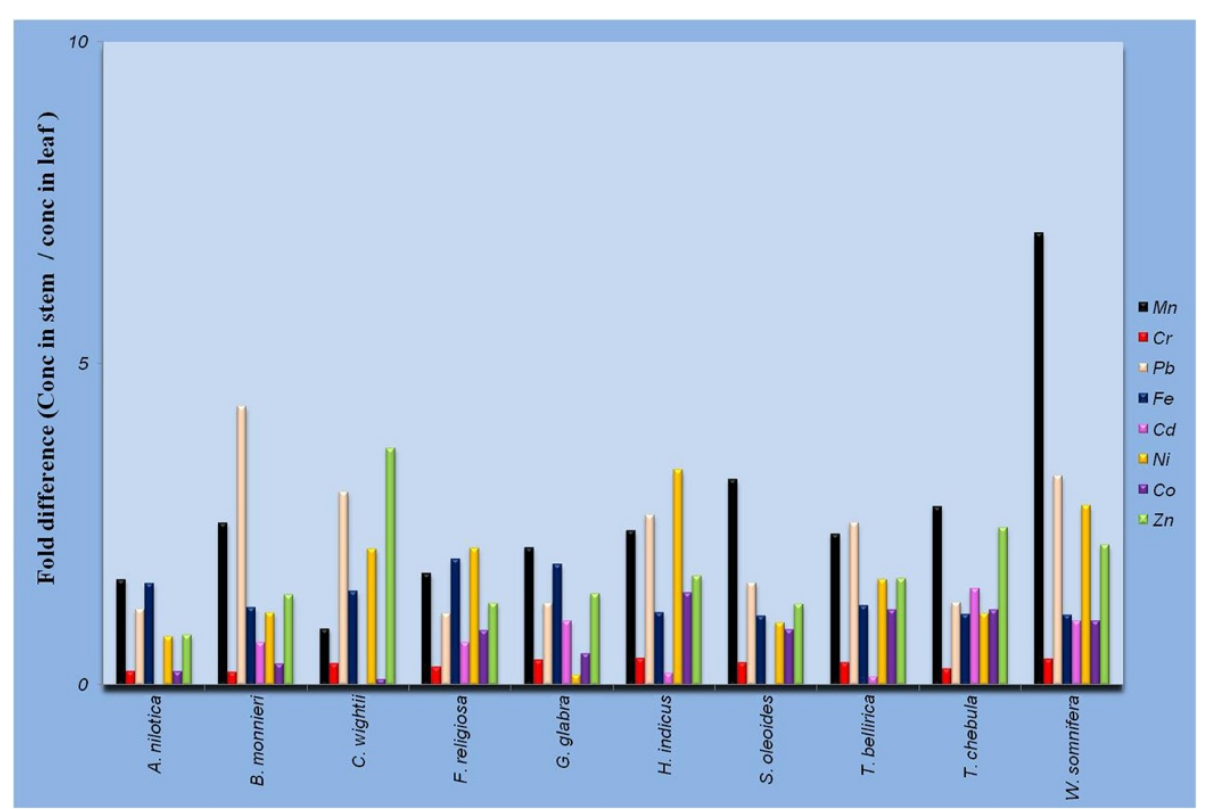

Figure 3 Fold difference in concentration of heavy metals in stem samples compared to respective leaf samples (conc. in stem sample/conc. in leaf sample).

(Bhat et al., 2010). In the present investigation, less than $2 \mathrm{ppm} \mathrm{Ni}$ concentration was found in all the samples. $\mathrm{Ni}$ concentration was 2.0-3.3 folds more in stem samples in C. wightii, F. religiosa, $H$. indicus and $W$. somnifera. Concentration of $\mathrm{Co}$, another major cause of contact dermatitis next only to nickel and chromium (Basketter et al., 2003), was less than $0.2 \mathrm{ppm}$ in all the stem and leaf samples. Co concentration was comparable in stem and leaf samples in most of the plants studied except $A$. nilotica, B. monnieri, C. wightii and G. glabra where it was more in leaf samples.

Zinc $(\mathrm{Zn})$ is an essential component of thousands of proteins in plants, although it is toxic in excess quantities. Maximum amount of zinc was found in stem samples of $W$. somnifera $(8.93 \pm 0.0264 \mathrm{ppm})$, followed by C. wightii $(7.74 \pm 0.0802 \mathrm{ppm})$ while in leaf samples

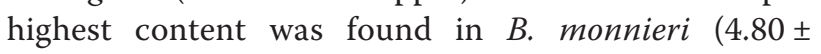
$0.0907 \mathrm{ppm}$ ) followed by $H$. indicus $(4.18 \pm 0.0212 \mathrm{ppm})$. Concentration of $\mathrm{Zn}$ was 2.0-3.7 folds more in stem samples of C. wightii, T. chebula and W. somnifera, while it was comparable in stem and leaf samples of other species tested. In Canada, $0.2 \mathrm{ppm}$ has been prescribed as the limit of mercury $(\mathrm{Hg})$ in raw herbal material, whereas in finished herbal products it is $0.02 \mathrm{mg} /$ day. In China and Singapore however, $0.5 \mathrm{ppm}$ limit has been proposed by WHO (2007). Hg concentration was below detectable limits in all the leaf and stem samples analyzed during this study. Radwan and Salama (2006) evaluated the level of $\mathrm{Pb}, \mathrm{Cd}, \mathrm{Cu}$ and $\mathrm{Zn}$ in various fruits and vegetables sold in Egyptian markets and found that their concentration was significantly higher but below the acceptable range in strawberries, cucumber, date and spinach. On the other hand, level of four most hazardous heavy metals $\mathrm{Pb}, \mathrm{Cd}, \mathrm{Cu}$ and $\mathrm{Cr}$ were found beyond the permitted limits in Glycyrrhiza glabra, Onosma bracteatum, Viola odorata, Foeniculum vulgare, Cuminum cyminum, Coriandrum sativum and Zingiber officinalis collected from southern, eastern, and western zones of Karachi, Pakistan (Hina et al., 2011).

Significant variation in metal concentration depending upon the plant species was recorded in the present study. Concentration of all heavy metals apart from $\mathrm{Cr}$ was found below the permissible limits in the stem and leaf samples of the ten medicinal plant species tested irrespective of their collection sites. Leaf samples had consistently more $\mathrm{Cr}$ compared to respective stem samples. Similarly, ten medicinal plants studied by Ajasa et al., (2004) collected from different areas of Ogbomoso revealed variable metallic levels. A higher mean level was obtained regarding $\mathrm{Pb}, \mathrm{Zn}$ and $\mathrm{Cu}$ in Azadirachta indica and Hyptis suaveolens. Gajalakshmi et al., (2012) analyzed six heavy metals $(\mathrm{Ni}, \mathrm{Cu}, \mathrm{Cr}, \mathrm{Zn}, \mathrm{Mn}, \mathrm{Pb})$ in four medicinal plant species and revealed similar results. They reported that $\mathrm{Cu}$ concentration was higher in leaf samples of all the species, although lower than permissible limit, whereas $\mathrm{Cr}$ concentration was at higher level in all the plants, $\mathrm{Zn}$ and $\mathrm{Mn}$ were below the tolerable edge, whereas $\mathrm{Ni}$ and $\mathrm{Pb}$ were completely missing in all the analyzed samples.

The rise in $\mathrm{Cr}$ concentration in Bahadurgarh region (heavy industrial area located at the edge of national 
capital New Delhi) in the present study can be attributed to fast industrialization, higher vehicle density and rapid urbanization. Princewill-Ogbonna and Ogbonna (2011) also reported that fast urbanization in developed cities is responsible for drastic increase of metal concentration in surrounding areas and plant species growing on those sites. They reported that higher liberation of vehicular pollutants in Aba city of Nigeria exhibited variable accumulation of heavy metals in different medicinal plants as demonstrated by AAS mediated chemical profiling. Similarly, analytical profile of $\mathrm{Pb}, \mathrm{Cd}, \mathrm{Cr}, \mathrm{Ni}, \mathrm{Sn}, \mathrm{Zn}, \mathrm{Mn}$, $\mathrm{Cu}$ and $\mathrm{Fe}$ exhibited concentrations at levels higher than permissible limits in various spice and medicinal plant species collected from exportation areas of Egypt (AbouArab and Abou Donia, 2000). Baranowska et al., (2002) evaluated the level of five heavy metals $(\mathrm{Pb}, \mathrm{Zn}, \mathrm{Cd}, \mathrm{Ni}$ and Mo) in six medicinal plants through FAAS from different heavily polluted locations and concluded that all the metals were higher in concentration at Express highways, Railway stations and urban roads.

The present study concluded that bio-accumulation of heavy metals increased with rise in their trophic levels, therefore, constant utilization of the herbs and vegetables may escort its metal level in humans as also reported by Akinola et al., (2008). Highly contaminated sites are responsible for heavy metal accumulation in plant parts, utilized either raw or as finished herbal products. According to an All India Ethnobiological Survey carried out by the Ministry of Environment \& Forests, Government of India, there are over 8000 species of plants being used by the people of India for medicinal purposes (Planning Commission Report, 2000). Therefore, the raw material collection sites need to be considered for their sporadic assessment for quality declaration and utilization. The medicinal plants-related trade in India estimated at Rs 5000 crores per annum with an annual growth rate of 7-15\% (Joshi et al., 2004), may face serious consequences if heavy metal accumulation beyond permissible limits is detected. Therefore, assessment of these hazardous metals in raw herbal material and finished products must be undertaken compulsorily. Recently, studies have been initiated for detection of heavy metals in many medicinal plants (Hussain et al., 2011; Baye and Hymete, 2010; Meena et al., 2010) utilizing AAS. Concentration of $\mathrm{Pb}$ and $\mathrm{Cd}$ was more than the permissible limits recommended by WHO for some medicinal plants analyzed by Baye and Hymete (2010). Instrumental neutron activation analysis and AAS of five heavy metals $(\mathrm{Cr}, \mathrm{Ni}, \mathrm{Cd}, \mathrm{As}$ and $\mathrm{Pb})$ and seven essential metals (V, Mn, Fe, Co, Cu, Zn, Se) from Khetri copper mine and those in fertile soils of Haridwar, India exhibited a wide variation in heavy metal concentration sketch. Concentrations of $\mathrm{Cu}, \mathrm{Cr}, \mathrm{Cd}$ and $\mathrm{Pb}$ were higher in Khetri copper mine as compared to Haridwar samples, whereas $\mathrm{Ni}$, As and other essential metals showed little variation in both the collection sites (Maharia et al., 2010). It was also reported that Withania somnifera showed highest bio-accumulation of metals as compared to Ocimum sanctum, Cassia fistula, and Azadirachta Indica.

\section{Conclusions}

Medicinal plants are sources of a large number of active principles of herbal and modern medicine. Indian people have a tremendous passion for medicinal plants and use them for a wide range of health related applications from a common cold to cancer and treatment of poisonous snake bites to a cure for genetic disorders like muscular dystrophy. India has one of the richest herbal medical cultures in the world that is of tremendous contemporary relevance ensuring health security to millions of people. However, continuous increase in environmental pollution is leading to built up of these pollutants including heavy metals in the plant parts which eventually enter the human food chain. Therefore, regular screening of raw material is must to check the levels of these pollutants in the plant parts and extracts before using them for human consumption. The present investigation clearly demonstrated the variation in heavy metal concentration depending upon the collection sites. Different countries have proposed different national limits for various heavy metals in raw herbal materials e.g the minimum permissible limits for arsenic, lead, cadmium, mercury and chromium are 5.0, 10.0, 0.3, 0.2 and $2.0 \mathrm{ppm}$ respectively in Canada while the same are 2.0, 10.0, 1.0, $0.5 \mathrm{ppm}$ respectively in China, and the limit has not yet been prescribed for chromium (WHO, 2007). However, the permissible limits have not been prescribed for many metals which are considered micronutrients. The developed AAS technique is a precise, specific and accurate method for estimation of heavy metal content in stem and leaf samples of these medicinal plants. Assessment of heavy metals in medicinal plants will pave the way for excluding extensively polluted environmental sites for collection of raw materials required for herbal drug preparation.

\section{Competing interests}

The authors declare that they have no competing interests.

\section{Authors' contribution}

AK, AS and SB conducted the experiments, SS analyzed the data, AC and RKK designed the research experiments and arranged the research facilities. All authors read and approved the final manuscript.

\section{Acknowledgement}

AK thankfully acknowledges the financial assistance provided by Department of Biotechnology, Government of India, New Delhi, under the project sanctioned vide order no. BT/PR10526/NDB/51/164/2008.

\section{Author details}

${ }^{1}$ Department of Bio and Nanotechnology, Guru Jambheshwar University of Science and Technology, Hisar 125001, India. ${ }^{2}$ Department of Environmental Science and Engineering, Guru Jambheshwar University of Science and 
Technology, Hisar 125001, India. Indian Agricultural Statistics Research Institute, Library Avenue, Pusa, New Delhi, India. ${ }^{4}$ Central Arid Zone Research Institute (CAZRI), Jodhpur, Rajasthan 342003, India.

\section{Received: 3 October 2013 Accepted: 11 December 2013} Published: 17 December 2013

\section{References}

Abou-Arab AA, Abou Donia MA (2000) Heavy metals in Egyptian species and medicinal plants and the effect of processing on their levels. J Agric Food Chem 48:2300-2304

Ajasa MA, Bello OM, Ibrahim OM, Ogunwande Al, Olawore ON (2004) Heavy trace metals and macronutrients status in herbal plants of Nigeria. Food Chem 85:67-71

Akinola MO, Njoku KL, Ekeifo BE (2008) Determination of Lead, Cadmium and Chromium in the tissue of an economically important plant grown around a textile industry at Ibeshe, Ikorodu Area of Lagos State, Nigeria. Adv Environ Biol 2:25-30

Ali A, Akhtar N, Khan BA, Khan MS, Rasul A, Zaman SUZ, Khalid N, Waseem K, Mahmood T, Ali L (2012) Acacia nilotica: a plant of multipurpose medicinal uses. J Med Plant Res 6:1492-1496

Annan K, Kojo Al, Cindy A, Asare-Nkansah S, Tunkumgnen BM (2010) Profile of heavy metals in some medicinal plants from Ghana commonly used as components of herbal formulations. Pharmacognosy Res 2:41-44

AOAC (1995) Official methods of analysis of AOAC International, 16th edn. AOAC International, Arlington, USA

Baranowska I, Srogi K, Włochowicz A, Szczepanik K (2002) Determination of heavy metal contents in samples of medicinal herbs. Pol J Environ Stud 11:467-471

Basketter DA, Angelini G, Ingber A, Kern PS, Menné T (2003) Nickel, chromium and cobalt in consumer products: revisiting safe levels in the new millennium. Contact Dermatitis 49:1-7

Baye H, Hymete A (2010) Lead and Cadmium accumulation in medicinal plants collected from environmentally different sites. Bull Environ Contam Toxicol 84:197-201

Bhat R, Kiran K, Arun AB, Karim AA (2010) Determination of mineral composition and heavy metal content of some nutraceutically valued plant products. Food Anal Methods 3:181-187

Gajalakshmi S, Iswarya V, Ashwini R, Divya G, Mythili S, Sathiavelu A (2012) Evaluation of heavy metals in medicinal plants growing in Vellore District. Eur J Exp Biol 5:1457-1461

Gupta S, Porwal MC, Roy PS (2004) Indigenous knowledge on some medicinal plants among the Nicobari Tribe of Car Nicobar Island. Indian J Tradit Know 3:287-293

Hina B, Rizwani GH, Naseem S (2011) Determination of toxic metals in some herbal drugs through atomic absorption spectroscopy. Pak J Pharm Sci 24:353-358

Hussain I, Ullah R, Khurram M, Ullah N, Baseer A, Khan FA, Khan N, Khattak MR, Zahoor M, Khan J (2011) Heavy metals and inorganic constituents in medicinal plants of selected districts of Khyber Pakhtoonkhwa, Pakistan. Afr J Biotechnol 42:8517-8522

Joshi K, Chavan P. Warude D, Patwardhan B (2004) Molecular markers in herbal drug technology. Curr Sci 87:159-165

Kloke A, Sauerback DR, Vetter H (1984) The contamination of plants and soils with heavy metals and the transport of metals in terrestrial food chains. In: Nriagu JO (ed) Changing Metal Cycles and Human Health. Springer-Verlag. Berlin, pp 113-141

Krausse R, Bielenberg JBW, Ullmann U (2004) In vitro anti-Helicobacter pylori activity of extractum liquiritiae, glycyrrhizin and its metabolites. J Antimicrob Chemother 54:243-246

Kulhari A, Sheorayan A, Kalia S, Chaudhury A, Kalia RK (2012) Problems, progress and future prospects of improvement of Commiphora wightii (Arn.) Bhandari, an endangered herbal magic, through modern biotechnological tools: a review. Genet Resour Crop Evol 59:1223-1254

Kunle OF, Egharevba HO, Ahmadu PO (2012) Standardization of herbal medicines-a review. Int J Biodivers Conserv 4:101-112

Lee SM, Lee WY (2002) Determination of heavy metal ions using conductometric biosensor based on sol-gel-immobilized urease. Bull Kor Chem Soc 23:1169

Maharia RS, Dutta RK, Acharya R, Reddy AVR (2010) Heavy metal bioaccumulation in selected medicinal plants collected from Khetri copper mines and comparison with those collected from fertile soil in Haridwar, India. J Environ Sci Health B 45:174-181
Makhija IK, Sharma IP, Khamar D (2010) Phytochemistry and pharmacological properties of Ficus religiosa: an overview. Ann Biol Res 1:171-180

Meena AK, Bansal P, Kumar S, Rao MM, Garg VK (2010) Estimation of heavy metals in commonly used medicinal plants: a market basket survey. Environ Monit Assess 170:657-660

Morgan A, Stevens J (2010) Does Bacopa monnieri improve memory performance in older persons? Results of a randomized, placebo-controlled, double-blind trial. J Altern Complement Med 16:753-759

Motamarri SN, Karthikeyan M, Kannan M, Rajasekar S (2012) Terminalia bellerica Roxb-a phytopharmacological review. Int J Res Pharma 3:96-99

Nies DH (1999) Microbial heavy metal resistance. Appl Microbiol Biotechnol 51:730-750

Nwoko CO, Mgbeahuruike L (2011) Heavy metal contamination of ready-to-use herbal remedies in south eastern Nigeria. Pakistan J Nutr 10:959-964

Olajire AA, Ayodele ET (2003) Study of atmospheric pollution levels by trace elements analysis of tree bark and leaves. Bull Chem Soc Ethiop 17:11-17

Planning Commission Report (2000) Report of the Task Force on conservation and sustainable use of medicinal plants. Planning Commission, Government of India., pp 1-194

Princewill-Ogbonna IL, Ogbonna PC (2011) Heavy metal content in soil and medicinal plants in high traffic urban area. Pakistan J Nut 10:618-624

Radwan AM, Salama AK (2006) Market basket survey for some heavy metals in Egyptian fruits and vegetables. Food Chem Toxicol 44:1273-1278

Rao NK, Srinivas N (2006) Antidiabetic and renoprotective effects of the chloroform extract of Terminalia chebula Retz. seeds in streptozotocin-induced diabetic rats. BMC Compl Alternative Med 6:17

Rao MR, Palada MC, Becker BN (2004) Medicinal and aromatic plants in agro-forestry systems. Agroforestry Syst 61:107-122

Saravanan N, Nalini N (2007) Impact of Hemidesmus indicus R.Br. extract on ethanol-mediated oxidative damage in rat kidney, Redox report. Free Radic Res Comm 12:229-235

Spanierman CS (2011) Iron toxicity in emergency medicine., http://emedicine. medscape.com/article/815213-overview\#showall

Szeto M (2007) Coriolus versicolor extracts: relevance in cancer management. Curr Oncol 14:41-47

Weber G, Konieczyński P (2003) Speciation of Mg, Mn and Zn in extracts of medicinal plants. Anal Biochem 375:1067-1073

Weiner MA, Weiner J (1994) Ashwagandha (Indian ginseng). In: Herbs that Heal. Quantum Books, Mill Valley, CA, pp 70-72

WHO (2007) Guidelines for assessing quality of herbal medicines with reference to contaminants and residues. World Health Organization, Geneva

Yadav JP, Saini S, Kalia AN, Dangi AS (2008) Hypoglycemic and hypolipidemic activity of ethanolic extract of Salvadora oleoides in normal and alloxan-induced diabetic rats. Indian J Pharmacol 40:23-27

Yamada K, Hung P, Park TK, Park PJ, Limb BO (2011) A comparison of the immunostimulatory effects of the medicinal herbs Echinacea, Ashwagandha and Brahmi. J Ethnopharmacol 137:231-235

Zhang Y, Rodionov DA, Gelfand MS, Gladyshev VN (2009) Comparative genomic analyses of nickel, cobalt and vitamin $B_{12}$ utilization. BMC Genomics 78:1-26

\section{doi:10.1186/2193-1801-2-676}

Cite this article as: Kulhari et al.: Investigation of heavy metals in

frequently utilized medicinal plants collected from environmentally diverse locations of north western India. SpringerPlus 2013 2:676.

\section{Submit your manuscript to a SpringerOpen ${ }^{\circ}$ journal and benefit from:}

- Convenient online submission

- Rigorous peer review

- Immediate publication on acceptance

- Open access: articles freely available online

- High visibility within the field

- Retaining the copyright to your article

Submit your next manuscript at $>$ springeropen.com 